\title{
Heterologous Soluble Expression of Recombinant OmpR of Aeromonas hydrophila and Its Immunogenic Potential
}

\author{
Sunita Kumari Yadav"\#, Carmelita N. Marbaniang2\#, Vibhuti Sharma1, Aparna Dixit ${ }^{1 *}$ \\ ${ }^{1}$ School of Biotechnology, Jawaharlal Nehru University, New Delhi, India \\ ${ }^{2}$ RNA Biology Group, Institute for Molecular Infection Biology, University of Würzburg, Würzburg, Germany \\ "Email: adix2100@mail.jnu.ac.in, adixit7@yahoo.com, adixit7@gmail.com
}

Received 18 May 2015; accepted 14 July 2015; published 17 July 2015

Copyright (C) 2015 by authors and Scientific Research Publishing Inc.

This work is licensed under the Creative Commons Attribution International License (CC BY).

http://creativecommons.org/licenses/by/4.0/

(c) (i) Open Access

\begin{abstract}
Aeromonas hydrophila, a gram negative bacterium is a major fish pathogen and causes major economic losses to aquaculture industry. Outer membrane proteins play a significant role in its survival during different environmental conditions and bacterial pathogenesis. The outer membrane protein $\mathbf{R}(\mathrm{OmpR})$ is a member of the two-component regulatory system of Aeromonas hydrophila which differentially regulates the expression of $\mathrm{OmpF}$ or $\mathrm{OmpC}$ depending on the osmolarity conditions. Role of OmpR has been demonstrated in its virulence in other infectious bacteria and it is found to be a potential drug target/vaccine candidate. However, the OmpR of $A$. hydrophila has not been characterized. In the present study, we report recombinant expression, purification of the OmpR of $A$. hydrophila strain Ah17 in salt inducible $E$. coli GJ1158 cells. Leaky expression of rOmpR was confirmed by Western blot analysis using anti- $6 \times$ His antibody. The histidine tagged recombinant OmpR (rOmpR) ( $29 \mathrm{kDa})$ was purified using Ni-NTA affinity chromatography from the soluble fraction of induced $E$. coli cells. The rOmpR was found to be highly immunogenic with end point titres of greater than 1:80,000. The anti-rOmpR antisera were capable of agglutinating live $A$. hydrophila cells, thus showing vaccine potential of the rOmpR.
\end{abstract}

\section{Keywords}

OmpR, Aeromonas, Cross-Reactivity, Outer Membrane Protein, Expression, E. coli GJ1158

\footnotetext{
${ }^{*}$ Corresponding author.

"These authors made equal contributions.
}

How to cite this paper: Yadav, S.K., Marbaniang, C.N., Sharma, V. and Dixit, A. (2015) Heterologous Soluble Expression of Recombinant OmpR of Aeromonas hydrophila and Its Immunogenic Potential. Advances in Bioscience and Biotechnology, 6, 443-451. http://dx.doi.org/10.4236/abb.2015.67044 


\section{Introduction}

Aeromonads, a heterogenous group of gram-negative bacteria have been associated with various pathological syndromes in fish, causing a major economic loss to the aquaculture industry [1]-[4] of various species of Aeromonads. Aeromonas hydrophila is of significance as it is one of the major species that infects fresh water fish. The treatment with antibiotics results in antibiotic-resistant strains, and water treatment with chemicals raises a great concern for the residues in the environment and food fish. Therefore, vaccination against infectious agents continues to be one of the most effective methods to control A. hydrophila infection. Till date, no vaccine is available for the treatment of infection against these bacteria. Vaccination strategies in fish farms have mostly involved the use of formalin killed pathogen [5] or live attenuated vaccines. Immunization with polyvalent vaccines, heat-killed and live attenuated Aeromonas hydrophila has been reported [6]-[9]. Biofilm of Aeromonas hydrophila has been shown to offer protection against bacterial challenge [10]. However, studies on immunization with a specific antigen(s) have remained limited to laboratories only. The outer membrane/surface proteins have been considered to be ideal candidates for vaccine development. Recently, recombinant outer membrane proteins OmpTS, OmpA and OmpW of A. hydrophila have been investigated for their immunogenic potential [11]-[13].

Several outer membrane components have been reported to be associated with the virulence of Aeromonas. The pathogenicity of the bacteria depends on their ability to survive and proliferate in the stressful environmental conditions which may change markedly during invasion of the host cells. Upon infection, bacteria are faced with a change in environmental conditions in the host and the ability of bacterium to survive in the changing environment plays a key role in its pathogenicity. In response to these changing environmental conditions, all bacteria display a complex regulation of gene expression by utilizing the signal transduction system referred to as the two components regulatory system [14] [15]. The OmpF and OmpC are two major porins, constituting $\sim 2 \%$ of the total cellular protein [16] in the outer membrane of bacteria whose expression is regulated in response to change in the osmolarity by two component regulatory system. The levels of these proteins are regulated by OmpR, a protein of two components regulatory systems [17].

The role of ompR and ompR-dependent genes in virulence has been well illustrated in Salmonella typhimurium [18] [19], Shigella flexineri [20] [21] Yersinia enterolitica [22] [23], and Helicobacter pylori [24]. It has been reported that the combined mutations in OmpF and OmpC result in avirulent $S$. typhimurium. Immunization with OmpR mutants of $S$. typhimurium fails to cause any mortality in BALB/c mice after oral challenge [19]. The OmpC protein has been indirectly reported to be involved in the adhesion and invasion of Crohn's disease-associated Escherichia coli strain LF82 [25]. Therefore, these proteins are important candidates for vaccine development. In addition, these proteins are present only in the bacterium and not in their hosts, and therefore can serve as a potential vaccine candidate or drug target for effective drug design. Since purification of the outer membrane protein to homogeneity from the bacteria is cumbersome due to significant similarity in their properties, recombinant route to produce the targeted protein is an attractive alternate. Present investigation reports production of soluble recombinant OmpR of A. hydrophila using heterologous E. coli expression system. The purified recombinant protein is then evaluated for its immunogenicity to assess its vaccine potential.

\section{Materials and Methods}

\subsection{Materials}

Expression vector pRSET-A was procured from Invitrogen USA. Reagents required for DNA modification (restriction enzymes and chemicals) were purchased from New England Biolabs, USA and Promega, USA. All other chemicals (analytical grade) used in the study were procured from Sigma-Aldrich Chemical Co., USA, unless otherwise stated. Oligonucleotides and primers used in the present study were synthesized by Microsynth, Switzerland.

\subsection{Bacterial Strains}

Aeromonas hydrophila (strain Ah17) was a kind gift from Dr. I. Karunasagar, College of Fisheries, Mangalore, India [26]. Escherichia coli DH5 $\alpha$ and BL21 (גDE3) pLysS were procured from Gibco-BRL, USA and Novagen, USA respectively. E. coli GJ1158 cells were used for recombinant expression of the OmpR [27]. 


\subsection{Cloning of the ompR Gene of A. hydrophila in Expression Vector}

The ompR gene of Ah17 along with upstream and downstream region was cloned in PBCKS+ cloning vector [28]. The full length gene encoding mature OmpR of A. hydrophila Ah17 was PCR amplified using pAhOmpR (EMBL acc no. AM084417.1) (Locus CAJ29527.1) [28] as the template and gene specific primers (Forward: 5'CCGCTCGAGATGCGGATCCTGTTGGTGG-3'; Reverse: 5'-ACCGGTACCTCATGCCCGGCCGTCCCGG CGC-3') containing XhoI and KpnI (in bold letters) in forward and reverse primers, respectively.

Polymerase chain reaction was performed at the following specified conditions: initial denaturation $94^{\circ} \mathrm{C}$ for 5 min followed by 25 thermal cycles of denaturation at $94^{\circ} \mathrm{C}$ for $45 \mathrm{~s}$; annealing at $53^{\circ} \mathrm{C}$ for $30 \mathrm{~s}$, extension at $72^{\circ} \mathrm{C}$ for $40 \mathrm{~s}$ with a final extension for $7 \mathrm{~min}$ at $72^{\circ} \mathrm{C}$. The XhoI- and KpnI-digested amplified OmpR fragment was ligated to pRSET-A prokaryotic expression vector digested with the same enzymes. Putative recombinants were screened using restriction enzyme digestion analysis, and integrity of the OmpR gene was confirmed by automated DNA sequencing (DNA sequencing facility, University of Delhi South campus, New Delhi). The resulting recombinant was designated as $p R S E T A h . o m p R$.

\subsection{Expression and Purification of Recombinant OmpR in E. coli}

Initial attempts to express the recombinant OmpR from pRSETAh.ompR in standard E. coli BL21(DE3) cells did not result in any expression. Subsequently, E. coli GJ1158 cells were used for recombinant expression after transformation with the $p R S E T A h . o m p R$. E. coli GJ1158 cells harboring the $p R S E T A h . o m p R$ were induced with the indicated concentrations of $\mathrm{NaCl}$ at $0.8 O . \mathrm{D}_{600 \mathrm{~nm}}$ and expression of the recombinant protein was analyzed at $6 \mathrm{~h}$ post-induction by SDS-PAGE (12\%) analysis. Optimization of inducer concentration was carried out by inducing the cells with different concentration of $\mathrm{NaCl}$ for $4 \mathrm{~h}$. Time of induction was optimized by inducing the cells with optimum $\mathrm{NaCl}$ concentration (determined earlier) for different time intervals. Localization analysis of the expressed protein was performed in the induced cell lysates essentially as described earlier [26]. The recombinant OmpR protein harboring the $6 \times$-histidine tag at the $\mathrm{N}$-terminus $(\mathrm{rOmpR})$ was purified from the soluble fraction under native conditions using $\mathrm{Ni}^{2+}$-NTA affinity chromatography. Briefly, LB (100 ml) containing 100 $\mu \mathrm{g} / \mathrm{ml}$ ampicillin was inoculated with $1 \%$ of $\mathrm{O} / \mathrm{N}$ grown culture of $E$. coli GJ1158 cells harboring $p R S E-$ TAh.ompR and incubated at $37^{\circ} \mathrm{C}$ with shaking $(200 \mathrm{rpm})$ till $\mathrm{A}_{600}$ reached 0.6 - 0.8. Induction of expression of the rOmpR was primarily done with $0.75 \mathrm{M} \mathrm{NaCl}$ for $6 \mathrm{~h}$ at $37^{\circ} \mathrm{C}$. The cells were harvested by centrifugation at $4000 \mathrm{rpm}$ for $10 \mathrm{~min}$ at $4^{\circ} \mathrm{C}$. After washing the pellet with Washing Buffer $(20 \mathrm{mM}$ Tris-HCl, pH 8.5, 20\% Sucrose), cells were lysed with $20 \mathrm{ml}$ of lysis Buffer (20 mM Tris-HCl, pH 8.5, $1 \mathrm{mM}$ EDTA, $1 \%$ Triton $\times 100$, $200 \mu \mathrm{g} / \mathrm{ml}$ lysozyme) by stirring vigorously for $10 \mathrm{~min}$ at RT. All protein purification steps were performed at $4^{\circ} \mathrm{C}$. Soluble fraction obtained after lysis was collected by centrifugation at 12,000 rpm for $20 \mathrm{~min}$. The rOmpR was purified from the soluble fraction using $\mathrm{Ni}^{2+} \mathrm{NTA}$ affinity chromatography essentially as described [26] Briefly, the rOmpR present in the soluble fraction was incubated with $\mathrm{Ni}^{2+}$-NTA slurry at $4^{\circ} \mathrm{C}$ for $2 \mathrm{~h}$ in binding buffer (5 mM imidazole, $20 \mathrm{mM}$ Tris- $\mathrm{HCl} \mathrm{pH} \mathrm{7.9,} 0.5 \mathrm{M} \mathrm{NaCl}$ ). Non-specific proteins were removed by washing the resin with 6 volumes of washing buffer (20 mM imidazole, $20 \mathrm{mM}$ Tris- $\mathrm{HCl} \mathrm{pH} \mathrm{7.9,} 0.5 \mathrm{M} \mathrm{NaCl})$. The specifically bound rOmpR was eluted with elution buffer $(200 \mathrm{mM}$ imidazole, $20 \mathrm{mM}$ Tris-HCl pH 7.9, $0.5 \mathrm{M}$ $\mathrm{NaCl}$ ). Different fractions were analyzed by SDS-PAGE. The fractions containing the purified rOmpR were pooled and subjected to dialysis in $20 \mathrm{mM}$ Tris-HCl, $\mathrm{pH} 7.9$ containing $10 \%$ glycerol. The purified rOmpR was stored at $-20^{\circ} \mathrm{C}$ in small aliquots until further use. Protein concentration was determined by the method of Lowry et al. [29] using bovine serum albumin as a standard.

\subsection{Western Blot Analysis}

The authenticity of the induced protein i.e. histidine tagged $\mathrm{rOmpR}$ in the induced cell lysates or the purified rOmpR was confirmed by Western blot analysis using anti-His or anti-rOmpR antibodies, respectively, essentially as described earlier [30]. Cell lysates or the rOmpR protein were resolved on 12\% SDS-PAG and transferred onto nitrocellulose (NC) membrane. The blot was incubated with $2 \%$ BSA in $1 \times$ PBS containing $0.05 \%$ Tween 20 (PBST) for $2 \mathrm{~h}$ at RT, followed by three subsequent washes with $1 \times$ PBST for $10 \mathrm{~min}$ each at RT. The membrane was then incubated with the anti- $6 \times$-His tag antibody $(1: 10,000)$ or anti-rOmpR antibody (1:5000) for $1 \mathrm{~h}$, followed by incubation with the alkaline phosphatase conjugated secondary antibody $(1: 10,000)$ for $1 \mathrm{~h}$ at RT. The membrane was given 3 washes with $1 \times$ PBST between each incubation. The immunoreactive bands were visualized by the Western blue stabilized substrate solution (Promega, USA). 


\subsection{Antibody Generation Against the rOmpR}

Female BALB/c mice (4 - 6 weeks) were used for immunization to generate polyclonal antibodies against the recombinant protein. The use of animals for the study was approved by the Institutional Animal Ethics Committee and prescribed guidelines by the Institutional Animal Ethics Committee, JNU, New Delhi, India were followed while handling the animals.

Primary immunization was carried out using the rOmpR (20 $\mu \mathrm{g} /$ mouse) emulsified in complete Freund's adjuvant. Booster doses with the same amount of the rOmpR in incomplete Freund's adjuvant were given on day 14, and day 28 of primary immunization. Mice were bled on day 0 (pre-immune sera), and a week after each immunization i.e. on day 21 and day 35. Sera collected prior to immunization served as control pre-immune serum. End-point titers of the antisera were determined using ELISA. Ability of the polyclonal antibodies to specifically recognize the rOmpR was also confirmed by Western blotting.

\subsection{Enzyme-Linked Immunosorbent Assay to Determine Antibody Titre}

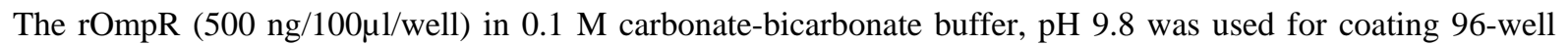
ELISA plate. After incubation overnight at $4{ }^{\circ} \mathrm{C}$, the plate was washed with $1 \times$ PBST thrice. Blocking was done with $2 \%$ BSA made in $1 \times$ PBST $\left(100 \mu \mathrm{l}\right.$ each well) for $2 \mathrm{~h}$ at $37^{\circ} \mathrm{C}$. Different dilutions of anti-sera (primary antibody) prepared in $1 \times$ PBS were added $(100 \mu \mathrm{l} /$ well $)$ and left for $2 \mathrm{~h}$ at $37^{\circ} \mathrm{C}$ followed by three washes with $1 \times$ PBST $(1 \times$ PBS containing $0.05 \%$ Tween-20). Alkaline phosphatase-conjugated anti-mice antibody raised in goat (Santacruz, USA) was used at a dilution of 1:10,000 (in $1 \times \mathrm{PBS}$ ) and incubated for $1 \mathrm{~h}$ at $37^{\circ} \mathrm{C}$. The plate was again washed three times with $1 \times$ PBST after every incubation. The substrate p-nitrophenylphosphate [100 $\mu \mathrm{l}$ of $1 \mathrm{mg} / \mathrm{ml}$ solution prepared in AP buffer ( $50 \mathrm{mM} \mathrm{Na}_{2} \mathrm{CO}_{3}, 1 \mathrm{mM} \mathrm{MgCl}_{2}$, $\mathrm{pH}$ 9.8)] was added to each well and left for $20 \mathrm{~min}$. The absorbance was read at $450 \mathrm{~nm}$ in an ELISA reader (Tecan, USA).

\subsection{Agglutination Assay}

The assay was performed to assess the ability of anti-rOmpR antisera to agglutinate live A. hydrophila cells essentially as described by Yadav et al. [30]. Briefly, A. hydrophila (Ah17) cells were inoculated in LB broth from an overnight culture and grown for $5-6 \mathrm{~h}$. For agglutination assay, $5 \times 10^{8}$ cfu from the log phase culture were taken and agglutination reaction set was made in $1 \times$ PBS containing 1:250 dilution of the anti-rOmpR antisera. Equal numbers of $A$. hydrophila (Ah17) cells in $1 \times$ PBS, with pre-immune sera, were included in the study as a control. The reaction mix was incubated for $1 \mathrm{~h}$ at $37^{\circ} \mathrm{C}$ followed by centrifugation at 5,000 rpm for $10 \mathrm{~min}$. The pellet was resuspended in $1 \times$ PBS. The resuspended cells were uniformly smeared on a clean glass slide and dried. The slide was heat fixed by passing through a flame transiently, and stained with methylene blue (SigmaAldrich Chemical Co, USA), followed by washing to remove the excess stain and visualised under microscope (Model Eclipse TE2000S, Nikon, USA).

\section{Results and Discussion}

A. hydrophila, a common fish pathogen, is responsible for causing major economic losses to the aquaculture industry. In addition to virulence factors expressed by the bacteria, its ability to adapt to different environments (outside and within the host) plays a critical role in its pathogenicity. This is conferred by the signal transduction system known as two components regulatory system. The OmpR is the key regulator of this system which controls the expression of OmpF and OmpC-the two major porins, differentially expressed under different osmolarity conditions. Role of OmpR and OmpR-dependent genes in bacterial virulence has been elucidated in a number of bacterial species and hence the proteins of this system become a potential drug target or vaccine candidates. We have earlier reported cloning and characterization of the OmpR gene of A. hydrophila [28] and in silico homology modelling of the OmpR of A. hydrophila for structure based drug design. However, for a protein to be evaluated as a vaccine candidate or drug target, large amounts of purified proteins are required. In the present study, we report soluble expression of recombinant OmpR of A. hydrophila and its purification, for evaluation of its immunogenic potential and ability to neutralize $A$. hydrophila.

\subsection{Cloning of the ompR Gene in E. coli Expression Vector}

Since the OmpR gene reported earlier contained 5'- and 3'-flanking sequences, including the signal sequence 
[28], cloning of the gene region encoding the mature OmpR in expression vector was carried out. PCR amplification of the OmpR encoding the mature OmpR resulted in amplification of $\sim 0.7 \mathrm{~kb}$ DNA fragment of the expected size. Successful cloning of the PCR amplified fragment after digestion with XhoI and KpnI in pRSETA resulted in in frame cloning, confirmed by DNA sequencing. The ompR gene with a single open reading frame would encode an $\mathrm{N}$-terminal $6 \times$-Histidine tagged recombinant OmpR of $\sim 29.5 \mathrm{kDa}$, including the amino acid residues contributed by the vector.

\subsection{Expression of the rOmpR in GJ1158 Cells}

For evaluation as a drug target or a vaccine candidate, the purified protein in its native form is required in large amounts which would not be feasible to purify from their natural source. It is particularly more difficult with reference to membrane proteins due to their similar properties. We have reported large scale purification of OmpF of A. hydrophila, a member of the two component regulatory system [30]. However, the protein expressed as inclusion bodies which adds additional steps for purification and refolding to its native conformation. General strategies to express soluble proteins in standard E. coli expression hosts such as M15, BL21(DE3) etc, involve lowering the concentration of IPTG, induction temperature etc. This slows down the cellular metabolism and cell proliferation. As a result, the yield of soluble protein is often compromised. We have used an alternate E. coli expression host GJ1158 cells, in which the T7 RNA polymerase gene has been placed under the control of osmotically inducible pro $\underline{U}$ promoter of $E$. coli [27]. These cells allow the use of standard expression plasmid in which the gene to be expressed is put under the control of T7 promoter. Successful expression of the rOmpR was obtained when the E. coli GJ1158 cells harboring the plasmid $p R S E T A h . o m p R$ were induced with $0.3 \mathrm{M}$ $\mathrm{NaCl}$ at $6 \mathrm{~h}$ post-induction. An intense band of approximately $29 \mathrm{kDa}$ of the rOmpR was seen in the induced (Figure 1(A), lane 2) as well as in uninduced cells (Figure 1(A), lane 1). This could be due to leaky expression of expressed protein in GJ1158 cells as the expression of the recombinant protein is not under as tight a control as seen with inducible promoters such as lac or tac. Since the OmpR homologue is present in E. coli, the protein is native to the host cell and hence leaky expression of the rOmpR would not adversely affect the cellular metabolism of the host cell. Unlike other membrane protein, MerT, which could not be expressed in GJ1158 cells due to expression induced toxicity [31], OmpR of A. hydrophila could be successfully expressed in these E. coli host cells. Use of $\mathrm{NaCl}$ as an inducer has an advantage over IPTG with respect to its low cost and relatively no toxicity. Western blot analysis using anti-His antibodies confirmed the authenticity of the rOmpR as a clear band at the expected position could be observed in the induced cells (Figure 1(B), lane 1). To obtain maximum expression of rOmpR, cultures induced with different concentrations of $\mathrm{NaCl}(0.1 \mathrm{M}-1 \mathrm{M}$; Figure $1(\mathrm{C})$ ) were analysed for the rOmpR expression. As evident from the figure, maximum expression was obtained with $0.75 \mathrm{M}$ $\mathrm{NaCl}$ (indicated on top of the panel). Time kinetics of expression revealed maximum expression of the rOmpR at $6 \mathrm{~h}$ post-induction (Figure 1(D)).

\subsection{Localization and Purification of the rOmpR}

Since the rOmpR is being expressed to ultimately evaluate its potential as a drug target or vaccine candidate, it is imperative to have the protein expressed as a soluble protein. Expression of soluble protein facilitates its structural characterization which is necessary for drug designing. Also, the soluble protein in its native form would retain conformational epitopes to bring about effective immune response. Analysis of the soluble and insoluble fractions of the induced cell lysates clearly showed that the rOmpR predominantly expressed in the soluble fraction (Figure 1(E). lane 1), although little expression could also be seen in the insoluble fraction (Figure 1(E), lane 2). Soluble expression of the rOmpR was achieved without addition of arginine, which is often used to direct the expression of aggregation-prone recombinant proteins in soluble fraction [32]. Our results are in agreement with Bhandari and Gowrishankar [27], who clearly demonstrated that induction with $\mathrm{NaCl}$ reduced sequestration of the overexpressed recombinant proteins within insoluble inclusion bodies. These authors attributed this to accumulation of glycine betaine, a component of yeast extract, upon osomotic shock with $\mathrm{NaCl}$ in GJ1158, which has earlier been reported to alleviate inclusion body formation of overexpressed dimethylallyl pyrophosphate: 5' AMP transferase of agrobacterium [33]. Soluble rOmpR was purified from the soluble fraction of induced cell lysates in a single step $\mathrm{Ni}^{2+}$-NTA chromatography. The rOmpR eluted with $200 \mathrm{mM}$ imidazole (Figure 1(E), lane 3) was purified to near homogeneity (98\%) based on the densitometric analysis. Approximately, $20 \mathrm{mg}$ of purified soluble rOmpR could be obtained from 1 liter of culture at shake flask level. Soluble 
(A)

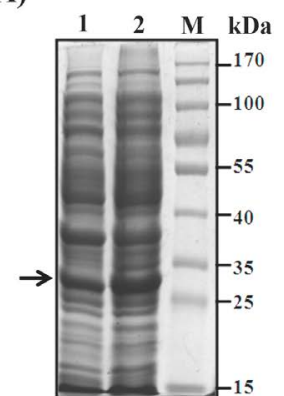

(C)

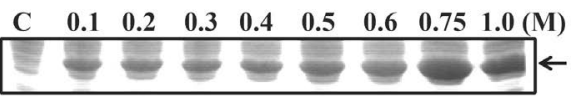

(D)

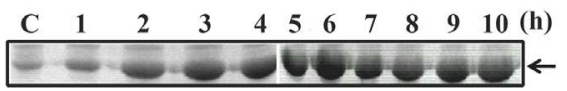

(E)

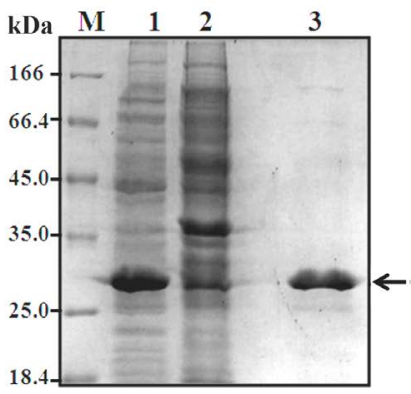

(B)

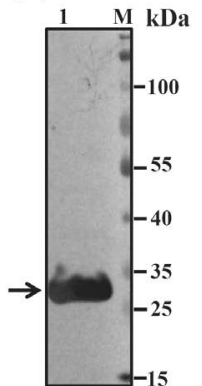

(h)

Figure 1. Recombinant expression of OmpR of Aeromonas hydrophila (A) E. coli GJ1158 cells harbouring pRSETAh.ompR were induced with $0.75 \mathrm{M} \mathrm{NaCl}$. Total cell lysates of the uninduced cells and induced cells are shown in lanes 1 and 2, respectively. The arrow points to the rOmpR of $\sim 29 \mathrm{kDa}$. (B) Western blot analysis of induced cell lysates (lane 1) using anti-His antibody (C) Optimization of inducer concentration for rOmpR expression. E. coli GJ1158 cells harboring pRSETAh.ompR were induced with different concentrations of $\mathrm{NaCl}(0.1 \mathrm{M}$ to $1 \mathrm{M}$, indicated on top of the panel) for $6 \mathrm{~h}$. Cell lysates (50 $\mathrm{ug}$ each) were analyzed on $12 \%$ SDS-PAGE. C refers to the uninduced cell lysates. The arrow points to the rOmpR. rOmpR expression could be seen at $\mathrm{NaCl}$ concentrations as low as $0.1 \mathrm{M}$. (D) Time kinetics of the rOmpR expression. Cell lysates of E. coli GJ1158 cells harboring pRSETAh.ompR induced with $0.75 \mathrm{M} \mathrm{NaCl}$ for different time periods ( 1 - $10 \mathrm{~h}$, shown on top of the panel) were analyzed by SDS-PAGE (12\%). Maximum expression of rOmpR is observed at 6 h. C refers to the uninduced cell lysates. The arrow points to the rOmpR (E) SDS-PAGE (12\%) analysis of the soluble (lane 1) and pellet (lane 2) fractions of the induced cell lysates. Lane 3 shows the rOmpR purified from the soluble fraction of induced cell lysates using Ni-NTA chromatography. M denotes protein molecular weight markers in all the panels.

rOmpR thus produced can be used for its structural characterization for effective drug design. Comparative densitometric analysis showed that, $\sim 1.5 \%-1.8 \%$ fold purification has been achieved. This is due to the reason that majority $(\sim 80 \%)$ of the total protein in the soluble fraction of the induced culture appeared to be recombinant OmpR.

\subsection{Specificity and Agglutination Ability of Anti-rOmpR Antisera}

The outer membrane proteins have been identified as primary targets for vaccine development, as these are exposed on the cell surface and are primary contact molecules with the host cell that is involved in generation of immune response [34]. A number of outer membrane proteins have been shown to be highly immunogenic amongst different bacteria and immunization with these proteins has been reported to confer protection against the bacterial challenge [35]-[39]. Likewise, the rOmpR was found to be highly immunogenic and resulted in generation of efficient immune response (Figure 2(A)). Significant immune response was observed even after single booster. The anti-rOmpR antisera with the end point titers of $\geq 80,000$ were obtained after first booster, which increased further after second booster. Immunoblot analysis of the induced cell lysates using anti-rOmpR antisera showed that the antisera was able to detect the expressed rOmpR as only a single band at the expected 


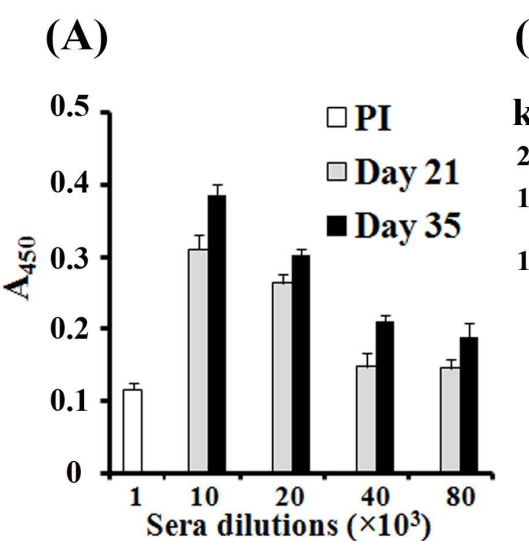

(B) (C)

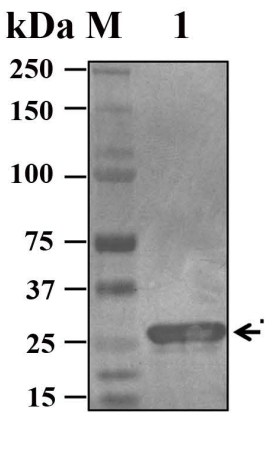

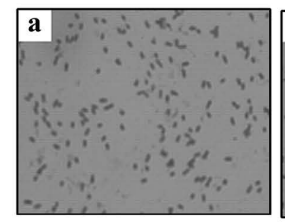

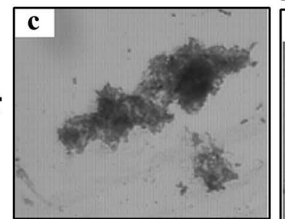

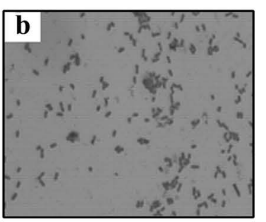

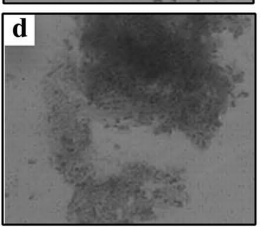

Figure 2. (A) End-point titer determination of the anti-rOmpR antisera. Antisera obtained from mice immunized with rOmpR at day 21 and day 35 was assessed for rOmpR-specific antibody titers by ELISA. Different dilutions of the anti-rOmpR antisera were added (in triplicate) to ELISA plates coated with purified rOmpR. Alkaline phosphatase-conjugated anti-mice antibody raised in goat were used as a detection tool. Aborbance at $450 \mathrm{~nm}$ measured 20 min after the substrate ( p-nitrophenylphosphate) is plotted against the antisera dilution. Preimmune (PI) serum was included as control. (B) Immunoblot analysis for the Specificity of the anti-rOmpR sera: Induced cell lysate of $E$. coli GJ1158 cells harbouring $p R S E-$ TAh.ompR were immunoblotted with anti-rOmpR antisera (1:5000) on nitrocellulose membrane. A dark immunoreactive band (pointed by arrow) visible only in the induced cell lysate (lane 1) confirms high specificity of the anti-rOmpR antisera. $\mathrm{M}$ indicates protein molecular weight $(\mathrm{kDa})$ marker $(\mathrm{C})$ Agglutination assay of anti-rOmpR antisera. Live A. hydrophila (strain Ah17), cells ( $5 \times 10^{8} \mathrm{CFU}$ each) in $0.5 \mathrm{ml}$ PBS were incubated with either pre-immune serum or anti-rOmpR antisera (1:250 dilution each). A. hydrophila cells pre-incubated with pre-immune sera shown in a, b whereas c, d show A. hydrophila incubated with anti-rOmpR antisera. Agglutination is evident only in A. hydrophila cells incubated with anti-rOmpR antisera. Images are taken at $40 \times$ magnification.

size in the induced cell lysate was observed (Figure 2(B)). Due to specific interaction of the antisera with the cell membrane, agglutination assays using serum have been routinely used for bacterial cell identification during an infection [40] [41]. Positive and specific agglutination indicates direct interaction of the antibodies present in the antisera with the bacterial cell. Therefore, neutralizing potential of the anti-rOmpR antisera was assessed by agglutination assay using live $A$. hydrophila cells. While incubation with pre-immune sera did not show any agglutination (Figure 2(C), panels a and b), the live A. hydrophila incubated with anti-rOmpR antisera resulted in effective clumping of cells (Figure 2(C) panels c and d). Potential of anti-rOmpR antisera to agglutinate live $A$. hydrophila cells clearly indicates the neutralizing activity of the antisera and its vaccine potential. Earlier studies from laboratory have demonstrated agglutination ability of the antisera generated against another outer membrane protein of two component regulatory system namely $\mathrm{rOmpF}$ [30]. It is possible that immunization with these two proteins i.e. rOmpR and rOmpF would further augment immune response that would be able to curtail Aeromonas infection.

\section{Conclusion}

The present studies thus establish soluble expression of rOmpR using $\mathrm{NaCl}$ as an inducer which makes the production cost effective in comparison to use of IPTG as an inducer. We also demonstrated immunogenic and vaccine potential of rOmpR of $A$. hydrophila which can be evaluated further in animals susceptible to A. hydrophila infection followed by challenge studies.

\section{Acknowledgements}

Authors acknowledge the Department of Biotechnology, Ministry of Science and Technology, New Delhi for research grant to AD. SKY thanks the Council of Scientific and Industrial Research, New Delhi for providing research fellowship.

\section{References}

[1] Abbott, S.L., Cheung, W.K.W. and Janda, J.M. (2003) The Genus Aeromonas: Biochemical Characteristics, Atypical Reactions, and Phenotypic Identification Schemes. Journal of Clinical Microbiology, 41, 2348-2357. 
http://dx.doi.org/10.1128/JCM.41.6.2348-2357.2003

[2] Behera, B., Bhoriwal, S., Mathur, P., Sagar, S., Singhal, M. and Misra, M.C. (2011) Post-Traumatic Skin and Soft Tissue Infection Due to Aeromonas hydrophila. Indian Journal of Critical Care Medicine, 15, $49-51$. http://dx.doi.org/10.4103/0972-5229.78228

[3] Cipriano, R.C. (2001) Aeromonas hydrophila and Motile Aeromonad Septicaemias of Fish. Revision of Fish Disease Leaflet 68, United States Department of Interior, Fish and Wildlife Service Division of Fishery Research, Washington DC, 1-25.

[4] Janda, J.M. and Abbott, S.L. (2010) The Genus Aeromonas: Taxonomy, Pathogenicity, and Infection. Clinical Microbiology Reviews, 23, 35-73. http://dx.doi.org/10.1128/CMR.00039-09

[5] Michel, C. (1979) Furunculosis of Salmonids: Vaccination Attempts in Rainbow Trout (Salmo gairdneri) by Formalin Killed Germs. Annales de Recherches Veterinaires, 10, 33-40.

[6] Chandran, M.R., Aruna, B.V., Logambal, S.M. and Michael, R.D. (2002) Immunisation of Indian Major Carps against Aeromonas hydrophila by Intraperitoneal Injection. Fish and Shellfish Immunology, 13, 1-9. http://dx.doi.org/10.1006/fsim.2001.0374

[7] Karunasagar, I., Ali, A., Otta, S.K. and Karunasagar, I. (1997) Immunization with Bacterial Antigens: Infections with Motile Aeromonads. Developments in Biological standardization, 90, 131-141.

[8] Majumdar, T., Ghosh, D., Datta, S., Sahoo, C., Pal, J. and Mazumder, S. (2007) An Attenuated Plasmid-Cured Strain of Aeromonas hydrophila Elicits Protective Immunity in Clarias batrachus. Fish and Shellfish Immunology, 23, 222-230. http://dx.doi.org/10.1016/j.fsi.2006.10.011

[9] Moral, C.H., Castillo, E.F.D., Fieroo, P.L., Cortes, A.V., Castillo, J.A., Soriano, A.C., Salazar, M.S., Peralta, B.R. and Carrasco, G.N. (1998) Molecular Characterization of the Aeromonas hydrophila aroA Gene and Potential Use of an Auxotrophic aroA Mutant as a Live Attenuated Vaccine. Infection and Immunity, 66, 1813-1821.

[10] Asha, A., Nayak, D.K., Shankar, K.M. and Mohan, C.V. (2004) Antigen Expression in Biofilm Cells of Aeromonas hydrophila Employed in Oral Vaccination of Fish. Fish and Shellfish Immunology, 16, 429-436. http://dx.doi.org/10.1016/j.fsi.2003.08.001

[11] Khushiramani, R., Girisha, S.K., Karunasagar, I. and Karunasagar, I. (2007) Protective Efficacy of Recombinant OmpTs Protein of Aeromonas hydrophila in Indian Major Carp. Vaccine, 25, 1157-1158. http://dx.doi.org/10.1016/j.vaccine.2006.10.032

[12] Maiti, B., Shetty, M., Shekar, M., Karunasagar, I. and Karunasagar, I. (2011) Recombinant Outer Membrane Protein A (OmpA) of Edwardsiella tarda, a Potential Vaccine Candidate for Fish, Common Carp. Microbiological Research, 167, 1-7. http://dx.doi.org/10.1016/j.micres.2011.02.002

[13] Maiti, B., Shetty, M., Shekar, M., Karunasagar, I. and Karunasagar, I. (2012) Evaluation of Two Outer Membrane Proteins, Aha1 and OmpW of Aeromonas hydrophila as Vaccine Candidate for Common Carp. Veterinary Immunology and Immunopathology, 149, 298-301. http://dx.doi.org/10.1016/j.vetimm.2012.07.013

[14] Mizuno, T. (1998) His-Asp Phosphotransfer Signal Transduction. Journal of Biochemistry (Tokyo), 123, 555-563. http://dx.doi.org/10.1093/oxfordjournals.jbchem.a021972

[15] Robinson, V.L., Buckler, D.R. and Stock, A.M. (2000) A Tale of Two Components: A Novel Kinase and a Regulatory Switch. Nature Structural and Molecular Biology, 7, 626-633. http://dx.doi.org/10.1038/77915

[16] Nikaido, H. Neidhardt, F.C., Curtiss III, R., Ingraham, J.L., Lin, E.C.C., Low Jr., K.B., Magasanik, B., Reznikoff, W.S., Riley, M., Schaechter, M. and Umbarger, H.E. (1996) Outer Membrane in Escherichia coli and Salmonella: Cellular and Molecular Biology. 2nd Edition, American Society for Microbiology Press, Washington DC, 29-47.

[17] Stock, J.B., Ninfa, A.J. and Stock, A.M. (1989) Protein Phosphorylation and Regulation of Adaptive Responses in Bacteria. Microbiological Reviews, 53, 450-490.

[18] Chatfield, S.N., Dorman, C.J., Hayward, C. and Dougan, G. (1991) Role of OmpR-Dependent Genes in Salmonella typhimurium Virulence: Mutants Deficient in Both OmpC and OmpF Are Attenuated in Vivo. Infection and Immunity, 59, 449-452.

[19] Dorman, C.J., Chatfield. S., Higgins, C.F., Hayward, C. and Dougan, G. (1989) Characterisation of Porin and OmpR Mutants of a Virulent Strain of Salmonella typhimurium: OmpR Mutants Are Attenuated in Vivo. Infection and Immunity, 57, 2136-2140.

[20] Bernardini, M.L., Fontaine, A. and Sansonetti, P.J. (1990) The Two-Component Regulatory System OmpR-EnvZ Controls the Virulence of Shigella flexneri. Journal of Bacteriology, 172, 6274-6281.

[21] Bernardini, M.L., Sanna, M.G., Fontaine, A. and Sansonetti, P.J. (1993) OmpC Is Involved in Invasion of Epithelial Cells by Shigella flexneri. Infection and Immunity, 61, 3625-3635.

[22] Brzostek, K., Raczkowska, A. and Zasada, A. (2003) The Osmotic Regulator OmpR Is Involved in the Response of Yersinia enterocolitica O:9 to Environmental Stresses and Survival within Macrophages. FEMS Microbiology Letters, 
228, 265-271. http://dx.doi.org/10.1016/S0378-1097(03)00779-1

[23] Raczkowska, A. and Brzostek, K. (2004) Identification of OmpR Protein and Its Role in the Invasion Properties of Yersinia enterocolitica. Polish Journal of Microbiology, 53, 11-16.

[24] Bury-Mone, S., Thiberge, J.M., Contreras, M., Maitournam, A., Labigne, A. and De Reuse, H. (2004) Responsiveness to Acidity via Metal Ion Regulators Mediates Virulence in the Gastric Pathogen Helicobacter pylori. Molecular Microbiology, 53, 623-638. http://dx.doi.org/10.1111/j.1365-2958.2004.04137.x

[25] Rolhion, N., Carvalho, F. and Darfeuille-Michaud, A. (2007) OmpC and the Sigma (E) Regulatory Pathway Are Involved in Adhesion and Invasion of the Crohn's Disease-Associated Escherichia coli Strain LF82. Molecular Microbiology, 63, 1684-700. http://dx.doi.org/10.1111/j.1365-2958.2007.05638.x

[26] Agarwal, S., Gopal, K., Upadhyaya, T. and Dixit, A. (2007) Biochemical and Functional Characterization of UDPGalactose 4-Epimerase from Aeromonas hydrophila. Biochimica et Biophysica Acta, 1774, 828-837. http://dx.doi.org/10.1016/j.bbapap.2007.04.007

[27] Bhandari, P. and Gowrishankar, J. (1997) An Escherichia coli Host Strain Useful for Efficient Overproduction of Cloned Gene Products with $\mathrm{NaCl}$ as the Inducer. Journal of Bacteriology, 179, 4403-4406.

[28] Chhabra, G., Upadhyaya, T. and Dixit, A. (2011) Molecular Cloning, Sequence Analysis and Structure Modeling of OmpR, the Response Regulator of Aeromonas hydrophila. Molecular Biology Reports, 39, 41-50. http://dx.doi.org/10.1007/s11033-011-0708-3

[29] Lowry, O.H., Rosebrough, N.J., Farr, A.L. and Randall, R.J. (1951) Protein Measurement with the Folin Phenol Reagent. Journal of Biological Chemistry, 193, 265-275.

[30] Yadav, S.K., Sahoo, P.K. and Dixit, A. (2014) Characterization of Immune Response Elicited by the Recombinant Outer Membrane Protein OmpF of Aeromonas hydrophila, a Potential Vaccine Candidate in Murine Model. Molecular Biology Reports, 41, 1837-1848. http://dx.doi.org/10.1007/s11033-014-3033-9

[31] Senthil, K. and Gautam, P. (2010) Expression and Single-Step Purification of Mercury Transporter (merT) from Cupriavidus metallidurans in E. coli. Biotechnology Letters, 32, 1663-1666. http://dx.doi.org/10.1007/s10529-010-0337-2

[32] Schaffner, J., Winter, J., Rudolph, R. and Schwarz, E. (2001) Co-Secretion of Chaperones and Low-Molecular-Size Medium Additives Increases the Yield of Recombinant Disulfide-Bridged Proteins. Applied and Environmental Microbiology, 76, 3994-4000. http://dx.doi.org/10.1128/AEM.67.9.3994-4000.2001

[33] Blackwell, J.R. and Horgan, R. (1991) A Novel Strategy for Production of a Highly Expressed Recombinant Protein in an Active Form. FEMS Microbiology Letters, 295, 10-12. http://dx.doi.org/10.1016/0014-5793(91)81372-F

[34] Osman, K.M. and Marouf, S.H. (2014) Comparative Dendrogram Analysis of OMPs of Salmonella enteric Serotype Enteritidis with Typhimurium, Braendurup and Lomita Isolated from Pigeons. International Journal of Advanced Research, 2, 952-960.

[35] Khushiramani, R., Maiti, B., Shekar, M., Girisha, S.K., Akash, N., Deepanjali, A., Karunasagar, I. and Karunasagar, I (2012) Recombinant Aeromonas hydrophila Outer Membrane Protein 48 (Omp48) Induces a Protective Immune Response against Aeromonas hydrophila and Edwardsiella tarda. Research in Microbiology, 163, 286-291. http://dx.doi.org/10.1016/j.resmic.2012.03.001

[36] Guan, R., Xiong, J., Huang, W. and Guo, S. (2011) Enhancement of Protective Immunity in European Eel (Anguilla anguilla) against Aeromonas hydrophila and Aeromonas sobria by a Recombinant Aeromonas Outer Membrane Protein. Acta Biochimica et Biophysica Sinica (Shanghai), 43, 79-88. http://dx.doi.org/10.1093/abbs/gmq115

[37] Pal, S., Theodor, I., Peterson, E.M. and de la Maza, L.M. (1997) Immunization with an Acellular Vaccine Consisting of the Outer Membrane Complex of Chlamydia trachomatis Induces Protection against a Genital Challenge. Infection and Immunity, 65, 3361-3369

[38] Guo, S.L., Lu, P.P., Feng, J.J., Zhao, J.P., Lin, P. and Duan, L.H. (2015) A Novel Recombinant Bivalent Outer Membrane Protein of Vibrio vulnificus and Aeromonas hydrophila as a Vaccine Antigen of American Eel (Anguilla rostrata). Fish and Shellfish Immunology, 43, 477-484. http://dx.doi.org/10.1016/j.fsi.2015.01.017

[39] Wright, J.C., Williams, J.N., Christodoulides, M. and Heckels, J.E. (2002) Immunization with the Recombinant PorB Outer Membrane Protein Induces a Bactericidal Immune Response against Neisseria meningitides. Infection and Immunity, 70, 4028-4034. http://dx.doi.org/10.1128/IAI.70.8.4028-4034.2002

[40] Kronvall, G. (1973) Rapid Slide-Agglutination Method for Typing Pneumococci by Means of Specific Antibody Adsorbed to Protein A-Containing staphylococci. Journal of Medical Microbiology, 6, 187-190. http://dx.doi.org/10.1099/00222615-6-2-187

[41] Svenungsson, B. and Linberg, A.A. (1978) Identification of Salmonella Bacteria by Co-Agglutination, Using Antibodies against Synthetic Disaccharide-Protein Antigens O2, O4 and O9, Adsorbed to Protein A-Containing staphylococci. Acta Pathologica et Microbiologica Scandinavica Section B, 86, 283-290.

http://dx.doi.org/10.1111/j.1699-0463.1978.tb00045.x 